\title{
Mumps infection with meningoencephalitis and cerebellitis
}

\author{
Tonyot Gailson 다, 'Viresh Vohra, ${ }^{1}$ Arushi Gahlot Saini 다, , Vikas Bhatia ${ }^{2}$
}

Pediatrics, PGIMER

Chandigarh, India

${ }^{2}$ Radiodiagnosis, PGIMER

Chandigarh, India

\section{Correspondence to} Dr Arushi Gahlot Saini; doc.arushi@gmail.com

Accepted 4 November 2021
Check for updates

(C) BMJ Publishing Group Limited 2021. No commercial re-use. See rights and permissions. Published by BMJ.

To cite: Gailson T, Vohra V, Saini $A G$, et al. BMJ Case Rep 2021;14:e247306. doi:10.1136/bcr-2021247306

\section{DESCRIPTION}

A 4-year-old boy presented with acute febrile illness with altered sensorium, decreased responsiveness to command, excessive sleepiness, headache and generalised-onset motor seizures for the past 2 days with intact bladder and bowel control. There was no history of jaundice, change in the colour of urine, skin rash, animal bite, recent travel or vaccination, focal motor deficits, cranial nerve palsies, extrapyramidal movements or neuropsychiatric problems. His medical and family history was unremarkable. He did not attend school, daycare or any public places preceding the illness due to COVID-19 pandemic. He was not immunised against the mumps virus.

On examination, he was drowsy with reduced spontaneous activity and interaction. $\mathrm{He}$ had photophobia, neck stiffness, Brudzinski's sign, Kerning's signs, brisk reflexes, bilateral Babinski's sign, normal muscle power and tone, normal fundi, a wide-based gait with tendency to fall on the left side, submandibular lymphadenopathy and a diffuse swelling in the bilateral parotid regions. The swelling extended from the ear to the angle of the mandible and was slightly tender suggestive of parotitis. Rest of the systemic examination was normal. A diagnosis of mumps meningoencephalitis with cerebellitis was considered. He was initiated on intravenous ceftriaxone and acyclovir. Laboratory investigations showed haemoglobin $76 \mathrm{~g} / \mathrm{L}$, platelet count $264 \times 10^{9} / \mathrm{L}$ and total leucocyte count $810 \times 10^{9} / \mathrm{L}$ (neutrophil $48 \%$, lymphocytes $38 \%$ and monocytes 14\%).

Total serum amylase was $240 \mathrm{U} / \mathrm{L}$ (normal range 30-100 U/L); further fractionation into salivary and pancreatic was not available in the laboratory. Cerebrospinal fluid (CSF) analysis showed clear fluid with 2667 cells/mL (23\% neutrophil and $77 \%$ lymphocytes), glucose $49 \mathrm{mg} / \mathrm{dL}$ (corresponding blood glucose level was $96 \mathrm{mg} / \mathrm{dL}$ ) and protein $122 \mathrm{mg} / \mathrm{dL}$. The gram stain and culture did not reveal any organism. Serology for scrub typhus and HIV was negative. Elevated IgM antibodies against mumps virus were detected by ELISA confirming mumps parotitis. MRI of the brain was done on day 3 of admission and showed hyperintensities in bilateral cerebellar, left parieto-occipital and parasagittal areas in bilateral frontal lobes with diffusion restrictions (figure 1A-F). With supportive care, the parotid swellings subsided in 4-5 days and the neurological symptoms recovered in 1 week.

Mumps is an acute, self-limiting infection caused by a single-stranded, pleomorphic RNA virus of the Paramyxoviridae family. Fever and unilateral or

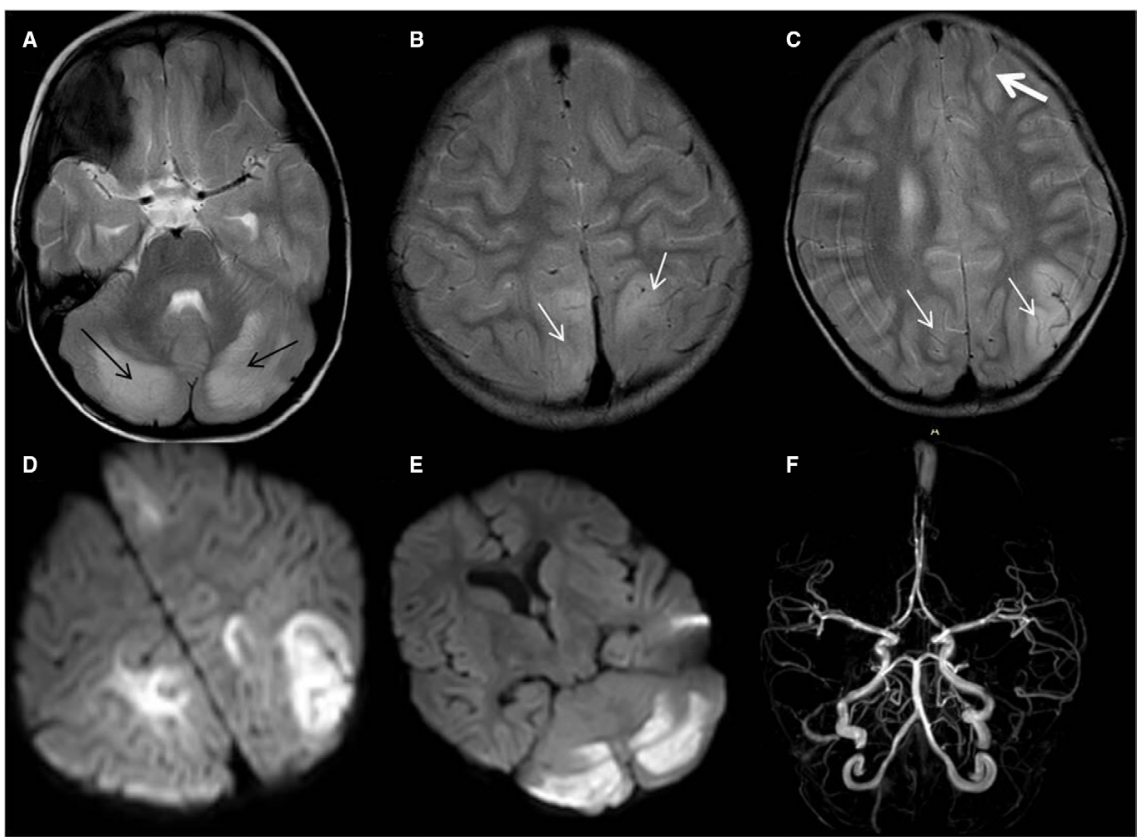

Figure 1 Axial T2-weighted image shows white matter changes in bilateral cerebellar hemispheres (black arrows; A), bilateral parietal lobes (thin white arrows; $B, C$ ) and left frontal lobe (thick white arrow; C). Diffusion-weighted images show marked diffusion restriction $(D, E)$. Time of flight magnetic resonance angiography shows normal findings (F). No abnormal meningeal or parenchymal enhancement was seen. 
bilateral parotid swelling characterise the acute illness. Mumps is uncommon in the developed nations due to widespread immunisation but it is still common in the developing countries. ${ }^{1}$ Central nervous system (CNS) is the next most common site of involvement after the salivary glands in children. Meningitis is seen in $1 \%-10 \%$ cases of mumps infections and the outcome is generally good. Mumps encephalitis is seen in $<1 \%$ of cases and may be fatal. ${ }^{12}$ The proposed pathological mechanism of mumps encephalitis is either due to the direct invasion of CNS by mumps virus in early stages causing primary meningoencephalitis or due to immune-mediated demyelination that usually occurs days to weeks after the acute onset of parotitis. ${ }^{2}$ Presence of concomitant meningitis and demyelination like acute disseminated encephalomyelitis can be seen in CNS infections like pneumococcus and Haemophilus influenzae, but is uncommon with mumps. ${ }^{3}$ In our case, clinical features and CSF examination were suggestive of meningoencephalitis but MRI of the brain showed multifocal involvement of subcortical white matter suggestive of parainfectious demyelination like acute disseminated encephalomyelitis.

\section{Learning points}

Mumps infection is still common in developing nations.

- Encephalitis is a rare but serious complication of acute mumps infection.

- Acute mumps infections may be accompanied by concomitant meningoencephalitis and self-limiting parainfectious demyelination.
Contributors TG-patient care, contributions to acquisition and analysis of data, drafting, final approval of the version to be published and agreement to be accountable for all aspects of the work. VV-patient care, substantial contributions to acquisition of data, drafting and final approval of the version to be published and agreement to be accountable for all aspects of the work. AGS - patient care, substantial contributions to the conception of work and interpretation of data, revising it critically for important intellectual content, drafting, final approval of the version to be published and agreement to be accountable for all aspects of the work. VB - substantial contributions to acquisition and interpretation of MRIs, final approval of the version to be published and agreement to be accountable for all aspects of the work.

Funding The authors have not declared a specific grant for this research from any funding agency in the public, commercial or not-for-profit sectors.

Competing interests None declared.

Patient consent for publication Parental/guardian consent obtained.

Provenance and peer review Not commissioned; externally peer reviewed.

Case reports provide a valuable learning resource for the scientific community and can indicate areas of interest for future research. They should not be used in isolation to guide treatment choices or public health policy.

\section{ORCID iDs}

Tonyot Gailson http://orcid.org/0000-0002-4062-5043

Arushi Gahlot Saini http://orcid.org/0000-0002-5747-8975

\section{REFERENCES}

1 Hviid A, Rubin S, Mühlemann K. Mumps. Lancet 2008;371:932-44.

2 Koskiniemi M, Donner M, Pettay 0. Clinical appearance and outcome in mumps encephalitis in children. Acta Paediatr Scand 1983;72:603-9.

3 Huhn K, Lee D-H, Linker RA, et al. Pneumococcal-meningitis associated acute disseminated encephalomyelitis (ADEM) - case report of effective early immunotherapy. Springerplus 2014;3:415

Copyright 2021 BMJ Publishing Group. All rights reserved. For permission to reuse any of this content visit https://www.bmj.com/company/products-services/rights-and-licensing/permissions/

BMJ Case Report Fellows may re-use this article for personal use and teaching without any further permission.

Become a Fellow of BMJ Case Reports today and you can:

- Submit as many cases as you like

- Enjoy fast sympathetic peer review and rapid publication of accepted articles

- Access all the published articles

- Re-use any of the published material for personal use and teaching without further permission

Customer Service

If you have any further queries about your subscription, please contact our customer services team on +44 (0) 2071111105 or via email at support@bmj.com.

Visit casereports.bmj.com for more articles like this and to become a Fellow 